\title{
EDITORIAL
}

\section{Efeitos Sócio-Econômicos do Turismo}

Uma avaliação dos efeitos sócio-econômicos do turismo consiste numa tarefa complexa, pelo seu caráter multisetorial; pelas dificuldades na obtenção de estatísticas necessárias e padronizadas para os diversos países envolvidos; e pelo atual estágio metodológico dos estudos e análises do Setor Serviços, onde se inclui o Turismo.

Dado seu caráter multisetorial, o turismo apresenta fortes interaçöes com os setores industrial e primário. Essa condiçäo requer que se promova um tratamento integrado na sua avaliação, o que, por si só, constitui-se num desafio metodológico a ser perseguido pelos estudiosos do setor e mesmo por aqueles que, especializados em outros campos da ciência - dadas as interfaces com o turismo -, possam contribuir para o aprofundamento do seu conhecimento.

Ao se buscar a integração com pesquisadores de outras áreas do saber - especificamente, no caso desta publicação, com a economia, a sociologia e alguns aspectos da ecologia -, está-se também atingindo dois outros objetivos: o acesso às estatísticas de fontes diversas daquelas tradicionalmente utilizadas nos estudos do turismo, e o tratamento do setor sob enfoques de naturezas econômica, social - com referência na área de segurança - $e$ ambiental. Tal fato pode ainda resultar num terceiro importante objetivo, qual seja o de colocar o turismo entre os setores produtivos considerados nos Programas de Desenvolvimento Econômico e Social.

Em raras oporturidades tem sido possivel a integração de profissionais e pesquisadores de outras áreas nos estudos de turismo. Como resultado desta ausência de complementaridade e de integração do conhecimento, o setor, embora reconhecidamente importante sob o enfoque econômico e social, não tem sido devidamente dimensionado em seus aspectos de beneficios e custos. Tem-se, em geral, um sentimento dessa importância, reforçado por estudos de alguma profundidade qualitativa, mas que não se traduzem em elemento concreto de informaçāo para a tomada de decisão, mais facilmente viabilizado com a adoção de modelos inter-disciplinares de avaliação e previsão.

Esta particular edição da Revista "Turismo em Análise" foi concebida com a pretenção de atingir esse propósito. E, pela felicidade da escoIha dos nomes, parece não restar dúvidas de que o processo de integração, se já anteriormente iniciado, viu-se fortalecido com a parti- 
cipação desses estudiosos renomados. No artigo Turismo e Renda na Economia Brasileira, desenvolvido por Marcio Ferreira Coelho, são apresentadas as estimativas preliminares de alguns importantes indicadores: a participaçăo do turismo no PIB - Produto Interno Bruto do País, da ordem de 2,2\% para o ano de 1988; o multiplicador de renda, igual a 1,75; a parcela da renda familiar destinada ao Turismo, $3 \%$ a.a.: e a importância relativa do turismo interno no País - gastos 3 vezes superiores aos dos estrangeiros.

O turismo pode ser tratado como setor estratégico em políticas de estabilizaçäo do nível de emprego? - A resposta é afirmativa, segundo os resultados preliminares obtidos por Ivo Torres, no artigo Turismo e Emprego na Economia Brasileira.

Um dos efeitos mais evidentes e esperados pelo desenvolvimento das atividades turísticas é a geração ou o consumo de divisas, resultante dos fluxos de viagens internacionais do País, respectivamente, como receptor ou emissor. Neste particular tema são apresentados dois trabaIhos, que se complementam: Câmbio Flutuante e Balanço de Pagamentos: Uma Análise Preditiva, de Clarice Pechman e Rodolfo Grandi, $e$ Turismo e Balanço de Pagamentos: Considerações e Simulações para o Brasil, de Renato G. Flores Jr. No estudo de Pechman e Grandi são apontadas as distorções das estatísticas oficiais sobre as receitas e despesas das viagens internacionais, basicamente causadas pelas defasagens, entre as políticas $e$ as práticas cambiais, $e$ são também identificadas associações entre as taxas de variação do ágio e um dado padrão sazonal de ingresso de turistas estrangeiros; com a adoção do "dólar turismo" (taxas flutuantes de câmbio), a partir de janeiro de 1989, a referida distorção é sensivelmente minimizada. São sugeridos ainda, baseados em séries históricas e em dados cambiais, modelos de previsão do fluxo turístico internacional - importante instrumento de decisão sobre a política de desenvolvimento setorial, de curto prazo, do turismo no Brasil. O estudo de Renato Flores apresenta um modelo de previsão baseado em 11 (onze) equações, compondo quatro blocos: exportações; balanço de pagamentos; mercado de trabalho; e geração de renda. Os dois últimos, por razões de significância estatística, não foram considerados na análise, que destaca os fatores relevantes a partir das elasticidades obtidas pelo modelo, entre esses, os fluxos de entrada de turistas estrangeiros. Enumera, ainda, uma série de medidas e proposiçōes, com vistas a melhorar os resultados gerados pelas atividades turísticas.

Uma questão que tem provocado muita controvérsia é a relativa ao turismo como fator de desenvolvimento regional e de distribuição de renda. Alguns países têm o turismo como atividade motriz de sua economia, mas prescindem de elementos de avaliação sobre essa opção política. O trabalho de Luiz Ablas - Efeitos do Turismo no Desenvolvimento Regional - busca mostrar em que condições esse setor pode desempenhar a função de promotor do desenvolvimento regional. Para isso, inicia seu trabalho com uma sistematização dos aspectos teóricos da questão regional e, na parte subsequente, descreve algumas das características das atividades turísticas e sua potencialidade na função de promover o desenvolvimento regional. Com base nestas colocações iniciais, formula algumas conclusões preliminares, destacando que, em economias regionais mais amplas e integradas, o turismo tende a apresentar resultados mais favoráveis, podendo, inclusive, constituir-se num setor propulsor de outras atividades produtivas na regiño.

O trabalho de Antonio Evaldo Comune - Turismo e Meio Ambiente na Amazônia: Perspectivas Econômicas do Turismo Ecológico analisa as possibilidades do desenvolvimento de uma região, no caso a Amazônia, a partir do turismo. Mais do que isso, ressalta a importância da ecologia e como este aspecto ambiental pode conviver com o crescimento do turismo - mais precisamente o Turismo Ecológico -, e com o de outras atividades produtivas, algumas das quais estimuladas por aquele setor. Formula algumas hipóteses de trabalho, a partir das quais são estimadas as participações do turismo interno e externo na formação da renda da região.

Turismo e Preços na Economia Brasileira é o tema desenvolvido por Juarez Rizzieri, que busca explicações teóricas nos movimentos de preços do setor. Por se tratar de uma atividade de natureza peculiar oferta, em geral, inelástica e localizaçōes distintas do consumidor relativamente à oferta turística -, propõe considerações especiais na análise da formação e nível de seus preços, diferenciando os casos em que a oferta é insuficiente daqueles em que a oferta é mais que suficiente, para atender as flutuaçöes da demanda; o primeiro caso provocando uma alta de preços e o segundo gerando ineficiência alocativa nos fatores de produção, cuja ociosidade resulta em maiores custos relativos.

Dois outros artigos, ligados ao tema de finanças públicas, encerram esta edição: Turismo na Constituição Brasileira de Ives Gandra da Silva Martins, e Estado, Turismo e Finanças Públicas, de Fernando Rezende, com a colaboração de Madalena Aurichio Valente. No primeiro trabalho é feita uma avaliação do turismo, à luz dos termos da Constituição, ressaltando capínulos que trataram de seu passado - quando se referem à proteção do patrimônio turístico, em geral (histórico, cultural, artístico, paisagístico etc) - e de seu futuro, quando se referem aos mecanismos de incentivos que o Estado deve ofertar às atividades turísticas. Ressalta ainda que as propostas concebidas para a atuação do Estado além de referirem-se à União, ao Estado e ao Distrito Federal -, são ex- 
tendidas à esfera dos Municipios, para os quais, em alguns casos, o turismo é de alto significado

zende situa as perspectivas do turismo face ao processo de modernização da economia, preconizado pelo Governo. Nesse processo são destacadas, entre outras, as propostas de revisão do papel do Estado, de formulação de um programa de privatizaçāo, de desregulamentação da economia $e$ de eliminaçăo de mecanismos de subsídios e incentivos fiscais, todas associadas à história recente do turismo no Brasil. Recomenda uma redistribuição das atribuiçōes governamentais em apoio ao turismo, ampliando as responsabilidades dos Estados e Municipios, beneficiários maiores da receita fiscal

mais importantes) quanto aos internacionais. A importância do turismo no orçamento governamental foi dimensionada num estudo de caso de 6 (seis) municípios tipicamente turísticos do Estado de São Paulo, pelo qual fica evidente a associação entre os movimentos dos fluxos turísticos e da receita tributária dessas localidades.

A riqueza de informaçōes constantes nesses trabalhos não permite que o estudo se esgote com suas publicaçōes. Alguns de seus autores iniciaram-se a este setor, apresentando resultados apenas preliminares, mas com sugestivas e promissoras abordagens no campo do turismo, revelando importantes indícios de seu significado

econômico de regiōes elou países. Os responsáveis técnicos desta Revista muito se orgulham de poder oferecer à comunidade da área e aos estudiosos em geral as importantes contribuiçöes oferecidas por esses pesquisadores/profissionais,

aprofundadas.

WILSON ABRAHÄO RABAHY*

Organizador desta Edição

(*) Professor Associado do Departamento de Relaçōes Públicas, Propaganda e Turismo da ECAVUSP. Membro da Comissão de Publicação da Revista "Turismo em Análise". 